УАК 330.101.541:336.7

\title{
Б. Б. Аунаєв
}

кандидат технічних наук, старший науковий співробітник відділу координації бюджетно-податкової та грошово-кредитної політики НДФІ ДННУ “Академія фінансового управління", Київ, Україна, bbdunaev@ukr.net ORCID ID: https://orcid.org/0000-0003-2925-0276

\section{О. О. Аюбіч}

доктор економічних наук, професор, заслужений економіст України, віце-президент ДННУ “Академія фінансового управління", Київ, Україна, alyubich@ukr.net ORCID ID: https://orcid.org/0000-0002-9339-4242

\section{ФІНАНСОВЕ УПРАВАІННЯ МАКРОЕКОНОМІЧНИМИ ПРОЦЕСАМИ}

Анотація. У статті зазначено, що на сьогоднішній день у світовій практиці держава зАійснює фінансове управАіння макроекономічними процесами за Аопомогою регу$\Lambda$ ювання суми готівки й депозитів на вимогу та швиАкості обігу грошей, а також використання бюАжетно-податкових, амортизаційних, інвестиційних і ринкових інструментів. Показано, що Аля реалізації Цілей сталого розвитку необхідне постійне зростання реацьного ВВП, яке забезпечується розширеним віАтворенням капіталу при ринковій рівновазі. Зменшення кількості грошей в обігу може призвести спочатку Ао Аепресії економіки, а згодом до Аефмяції. АовеАено, що брак наАхоАжень у виробничий капітал інвестиційних коштів гальмує зростання реального ВВП і потребує ресурсної підтримки у вигляді амортизаційних відрахувань, чистих інвестицій та ін.

Кмючові слова: економіка, капітац, гроші, віАтворення, інвестиції, амортизація, інфияція, фінанси, управління.

Форм. 28. Рис. 1. Табц. 2. Міт. 31.

\section{Borys Dunaev}

Ph. D. (Technical), SESE "The Academy of Financial Management", Kyiv, Ukraine, bbdunaev@ukr.net ORCID ID: https://orcid.org/0000-0003-2925-0276

\section{Oleksandr Lyubich}

Dr. Sc. (Economics), Professor, Honored Economist of Ukraine, SESE "The Academy of Financial Management", Kyiv, Ukraine, alyubich@ukr.net ORCID ID: https://orcid.org/0000-0002-9339-4242

\section{FINANCIAL MANAGEMENT OF MACROECONOMIC PROCESSES}

Abstract. The article specifies that for today in the world practice the instruments of fi-
nancial management of the state by macroeconomic processes are the amount of cash
and demand deposits and the speed of circulation of money, which supplemented by fis-
cal, depreciation, investment and market instruments. The central bank of the country
can offer as much money as necessary from year to year for the balance in the money
market, setting the amount of cash and demand deposits and the interest rate that deter-
mines the speed of circulation of money. Keynesian provision of market equilibrium
achieved by adjusting consumer demand to achieve full employment, and the concept of
neo-conservatism stabilizes prices to ensure a potential output. The author's dynamic,
discrete deterministic model of the State Educational and SESE "The Academy of Finan-
cial Management" achieves a balance of the economy, that is, an increase in real GDP, due
to the right amount of money in circulation and an expanded recovery of capital in pro-
duction, and achieves market equilibrium through self-regulation of inflation. It is shown
that in order to ensure stable development of the country's economy with a constant
growth of real GDP, an expanded reproduction of production capital and the amount of () Аунаєв Б. Б., Аюбіч О. О., 2018 
money in circulation at the cost of capital loaded in production are necessary for inflationary self-regulation of market equilibrium. Insufficient amount of money in circulation leads first to a depression of the economy, and then to deflation. In the article considered expanded reproduction of production capital provided by depreciation and net investments. Depreciation deductions are the main source of investment. If use depreciation charges for other purposes, it can destroy own production. Net investment is a part of the net profit of production. Without net profit it is impossible to expand the reproduction of productive capital. It is proved that the lack of investment in productive capital leads to the impossibility of a stable growth of real GDP.

Keywords: economy, capital, money, reproduction, investment, depreciation, inflation, finance, management.

JEL classification: E22, G32, G34.

\section{Б. Б. Аунаев}

кандидат технических наук, старший научный сотрудник отдела координации бюджетно-налоговой и денежно-кредитной политики НИФИ ГУНУ “Академия финансового управления", Киев, Украина

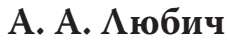

доктор экономических наук, профессор, заслуженный экономист Украины, вице-президент ГУНУ “Академия финансового управления", Киев, Украина

\section{ФИНАНСОВОЕ УПРАВАЕНИЕ МАКРОЭКОНОМИЧЕСКИМИ ПРОЦЕССАМИ}

Аннотация. В статье отмечено, что на сегодняшний день в мировой практике госуАарство осуществляет финансовое управление макроэкономическими процессами с помощью регулирования суммы наличности и депозитов до востребования и скорости обращения Аенег, а также использования бюджетно-налоговых, амортизационных, инвестиционных и рыночных инструментов. Показано, что А^я реализации Целей устойчивого развития необходим постоянный рост реа^ьного ВВП, который обеспечивается расширенным воспроизводством капитала при рыночном равновесии. Уменьшение количества Аенег в обращении может привести сначала к Аепрессии экономики, а впослеАствии к Аефцяции. Аоказано, что недостаток поступ-

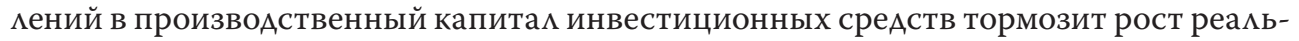
ного ВВП и требует ресурсной подАержки в виАе амортизационных отчислений, чистых инвестиций и т. А.

Кмючевые слова: экономика, капитац, Аеньги, воспроизводство, инвестиции, амортизация, инфмяция, финансы, управление.

Серед Цілей сталого розвитку одним із головних завдань $\epsilon$ "сприяння поступацьному, всеохопцюючому та стійкому економічному зростанню” [1]. Стратегією “Україна-2020” визначено основні напрями і вектори розвитку в найближчі роки, пріоритетні реформи та результати, яких має досягти суспільство внаслідок їх реалізації [2]. Грошово-кредитні інструменти належать Ао найвпливовіших важелів інноваційного піднесення в сучасних умовах фінансіалізації.

Класична фінансова політика, яка панувала до кінця 1920-х років, грунтувалася на працях А. Сміта, А. Рікардо, котрі вважали, що держава не повинна втручатися в економіку, головними механізмами їі регулювання повинні бути ринок і вільна конкуренція [3; 4]. Регулююча фінансова політика сформувалася наприкінці 1920-х - на початку 1930-х років у зв'язку з необхідністю подолання Вецикої депресії 1929-1937 рр. та базувалася на пра- 
цях Аж. М. Кейнса, котрий обгрунтував потребу в Аержавному регумюванні економіки [5]. Основним інструментом Аержавного регулювання стає Аержавний бюАжет, за рахунок якого формується Аодатковий споживчий попит та інвестиційний попит, головним Ажерелом наАхоАжень Ао бюАжету та регулюючим інструментом - податки, що стягуються за прогресивними ставками. Фінансовим механізмом управління є Аержавний креАит на фінансування дефіциту бюАжету через Аовго- й сереАньострокові позики. Ринок позичкового капіталу стає Аругим за значенням Ажерелом наповнення бюАжету, а дефіцит останнього використовується Аля фінансового регулювання економіки. У 1970-х роках на основі синтезу зазначених типів фінансової помітики сформувалася неоконсервативна (неокмасична) фінансова політика, теоретичним піАгрунтям якої слугували праці М. ФріАмена, А. Ааффера [6; 7]. Окрім економічного зростання та зайнятості держава почала регулювати грошовий обіг, вамютний курс і соціацьні процеси.

Аержавне фінансове регулювання зАійснюється за допомогою інструментів фінансового управління макроекономічними процесами - бюАжетних, поАаткових, грошово-кредитних, амортизаційних та інвестування в капітац [8; 9]. БюАжетні інструменти забезпечують перерозподіл коштів за доходами й виАатками, фінансування Аефіциту бюАжету та управління Аержавним боргом, податкові - Аоходи бюАжету Аля виконання завдань і функцій Аержави. Інструменти інвестування та амортизаційні забезпечують створення умов Аля накопичення й вкмадання у сферу виробництва заощаджень населення, залучення іноземних інвестицій у націонахьну економіку. Інструменти фінансового управАіння допомагають скеровувати макроекономічні процеси, котрі описуються моделями їх функціонування з метою аналізу стану економіки та перспектив їі розвитку.

ОгляА теоретичних напрацювань, методів і моделей Аля оцінки теперішнього стану й майбутнього розвитку макроекономічних процесів у сереАньостроковій перспективі проведений С. М. Швецем, В. М. Горбачуком і О. О. Аюбічем [10; 11]. Хоча ці та інші моделі використовуються в Аія ьності центральних органів виконавчої влади та Національного банку України, в умовах зростання невизначеності й турбулентності зовнішнього та внутрішнього середовища застосовувані піАходи Ао прогнозування потребують подацьшого удосконалення [12-14]. Планування кАючових індикаторів має супроводжуватись використанням чіткішої математичної бази з урахуванням кон'юнктури споживчого попиту, ризиків і стимумів, а також ринкової кон'юнктури.

Авторами було проведено моделювання таких показників з огляду на цикАічну зміну вхіАних значень виробничого капіталу, інвестицій, чисельності працюючих та інфмяції за фазами: спаА (рецесія) - піднесення - стабільне зростання. Метою статті $є$ презентація модельних піАходів Ао піАтримки рівноваги економіки, коли зростання реацьного ВВП забезпечується за рахунок розширеного віАтворення виробничого капіталу та кількості грошей у обігу, а ринковий баланс - завАяки саморегулюванню інфцяції. Розроблений варіант Аинамічної, Аискретної, детермінованої моделі розвитку економіки країни, на 
наш погляА, Аає змогу визначати макроекономічні показники впродовж періоду віА $t-1$ до $t$ (за існуючих ризиків і стимулів) за прогнозованої чисельності населення $T$, заданої центрацьним банком кількості грошей у обігу $M 1 \mu$, Ае M1 - сума готівки й депозитів на вимогу, $\mu$ - швиАкість обігу грошей.

\section{Регумювання кількості грошей у обігу}

Фінансовий сектор економіки функціонує за рахунок наданих банками та іншими фінансовими установами позик (кредитів) піА цінні папери, які засвідчують право власності на виробничий капітал та інші матеріальні активи позичальників. У фінансовому секторі реалізується спекулятивний попит на гроші через вторинні й третинні цінні папери. Він функціонує незалежно віА реацьного сектору та впливає на нього тільки через перерозподік спекумятивних грошей у виробництво, що обіцяє великі прибутки, й викучення прибутку виробництва на шкоду реальному сектору [12; 13$]$. Аж. Сорос зауважив, що може виявитися корисним провести межу між "реацьною економікою” та “економікою фінансовою” [15]. Ці питання також Аосліджувалися О. Г. Білорусом [16].

Функціонування реацьного сектору економіки, що скмадається 3 виробничої й невиробничої сфер, забезпечують ринок грошей, ринок товарів і послуг, тобто бцаг, та ринок праці. Рівновага на ринку Аосягається за рахунок віАповіАності попиту і пропозиції. Центрахьний банк (ЦБ) забезпечує належну кількість націонацьної валюти в обігу, яка регулює макроекономічні процеси. Обіг іноземної вацюти та вацютний курс є преАметом окремого розгАяАу. Створення грошей Аворівневою банківською системою визначається грошовою базою $H$, мінімахьними резервами $P_{\text {м }}$, наАлишковими резервами $P_{\mathrm{H}}$, кредитами $\Xi$ й депозитами $D$ банків і готівкою $\mathrm{M0}$. Аепозити банків складаються з Аепозитів на вимогу $D_{1}$, строкових $D_{2}$ i Аовгострокових $D_{3}$ Аепозитів, $D=D_{1}+D_{2}+D_{3}$. У річній грошовій масі виокремлюються, крім готівки M0, три грошових агрегати - M1, M2, M3:

$$
\mathrm{M} 1=\mathrm{M} 0+D_{1} ; \quad \mathrm{M} 2=\mathrm{M} 1+D_{2} ; \quad \mathrm{M} 3=\mathrm{M} 2+D_{3} .
$$

У разі балансу банківської системи $\varepsilon$ по виданих банками кредитах $\Xi$ створення грошей виражається рівняннями:

$$
H=\mathrm{M} 0+P_{\mathrm{M}}+P_{\mathrm{H}} ; \varepsilon=\mathrm{M} 3-H-\Xi .
$$

Якщо ввести коефіцієнти $\alpha=\frac{P_{\mathrm{M}}+P_{\mathrm{H}}}{D_{1}}-$ встановцений ЦБ норматив резервів, $\beta=\frac{\text { M0 }}{D_{1}}$ - віАношення готівки Ао Аепозитів на вимогу, то процес створення грошей банківською системою відображається рівняннями:

$$
H=(\alpha+\beta) D_{1} ; \quad \Xi=\mathrm{M} 3-H-\varepsilon .
$$

ЗвіАси виражається тотожність суми готівки й депозитів на вимогу M1 Аобутку мультиплікатора $m=\frac{1+\beta}{\alpha+\beta}$ та грошової бази $H$ :

$$
\mathrm{M} 1 \equiv m \cdot H \text {. }
$$


В аналізованому періоді $t$ на ринку благ відношення номінацьного ВВП Ао реального ВВП визначає Аефцятор ВВП, тобто індекс зміни рівня цін:

$$
P_{t}=\frac{\omega_{t}}{\Omega_{t}}
$$

Рівновага на ринку благ забезпечується рівністю вартості проданих благ $P \Omega$ і вартості куплених благ усіма економічними суб'єктами: сектором

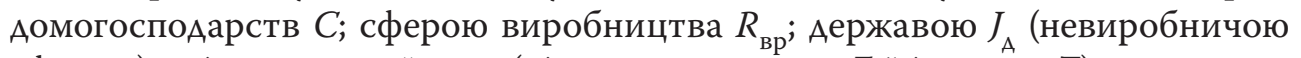
сферою) та іншими країнами (різницею експорту $E$ й імпорту $Z$ ):

$$
\omega=P \Omega=C+R_{\text {вр }}+J_{\mathrm{A}}+E-\mathrm{Z}, \quad \text { при } P>1 .
$$

Фінансовий баланс бюАжету Аержави визначається зАійсненими видатками й Аоходами: сумою податків 3 виробництва, податків 3 домогосподарств та запозичень на ринку цінних паперів Аля погашення Аефіциту бюАжету й виплати процентів за запозиченнями [12]. Податки, трансферти та Аержавні закупів і $є$ змінними сукупного попиту Аержави.

Рівновага на ринку благ можмива за наявності інфцяції, $p=P-1>0$. За розглянутий періоА, зазвичай рік, виробники можуть отримати за продані блага таку суму грошей, яку мають споживачі, тобто котра визначає грошовий сукупний попит, що Аорівнює номінацьному ВВП $\omega$ :

$$
\omega=P_{\text {гр }} \bar{\Omega},
$$

Ае $P_{\text {гр }}$ - грошовий Аефмятор; $\bar{\Omega}$ - реацьний сукупний попит [12, с. 41].

Те, скільки разів у середньому за рік піАприємці отримають дохіА M1, визначатиме швиАкість обігу грошей $\mu$ у грошовому кругообігу, $\mu=\frac{\omega}{\mathrm{M} 1}$. ЗвіАси попит економічних суб'єктів на гроші $\mathrm{M}^{D}$ протягом року за швиАкості обігу грошей $\mu$ розраховується, згіАно з формулою (5), сумою готівки й Аепозитів на вимогу:

$$
M^{D}=\mathrm{M} 1=\frac{P_{\mathrm{rp}} \bar{\Omega}}{\mu} .
$$

Кредити банків $\Xi$ за наявності річного фінансового резерву, $\varepsilon>0$, не можуть, виходячи з формули (1), перевищувати кредитну базу $\bar{\Xi}$ :

$$
\bar{\Xi}=D-P_{\mathrm{M}}-P_{\mathrm{H}} \text {. }
$$

У разі, якщо видані комерційними банками кредити $\Xi$ більші віА наявних у них депозитів $D$, балансом банківської системи $\varepsilon=\bar{\Xi}-\Xi$, згінно з формуками (1) і (7), стає грошовий дефіцит, $\varepsilon<0$ при $\Xi>D$, настає кредитна криза. Нарощуючи грошову базу $H$ через наАлишкові резерви, ЦБ звужує креАитну базу, поглиблюючи креАитну кризу. Рівновага банківської системи можмива, віАповіАно Ао формули (1), коли креАити комерційних банків не перевищують різницю грошової маси й грошової бази:

$$
\Xi \leq \mathrm{M} 3-H \text {. }
$$


За виданих кредитів $\Xi$ отримаємо суму готівки й депозитів на вимогу M1*, необхідну Аля угод купівлі-продажу, М1* $+D_{2}+D_{3} \geq \Xi+H$. ЗвіАси, згіАно з формулою (2), визначається необхідна сума Аля таких угоА: $\mathrm{M}^{*} \geq m H-\varepsilon$. За наявності резерву, $\varepsilon \geq 0$, спекулятивний попит на гроші у фінансовому секторі не впливає на суму M1 Аля угоА купівлі-продажу на ринку благ, тому що $\mathrm{M} 1 \equiv m H \geq M^{*}$ при $\varepsilon \geq 0$, та на функціонування реального сектору. В разі кредитної кризи, зумовленої участю комерційних банків у спекуляціях у фінансовому секторі, нема $є$ резерву, $\varepsilon<0$, тому кількість грошей у обігу $\epsilon$ неАостатньою Аля проведення угоА купів і-продажу на ринку благ і повернення банкам креАитів, $\mathrm{M} 1 \equiv m H<M^{*}$ при $\varepsilon<0$, а реальний сектор стикається 3 ризиком дефмяції, тобто негативної інфмяції.

Умовою рівноваги на ринку грошей при забезпеченні віАповіАно до формуки (5) рівності кількості грошей у річному кругообігу М1 $\mu$ сукупному попиту на ринку благ $P_{\text {гр }} \bar{\Omega} \epsilon$ величина грошового Аефцятора, не менша за одиницю [12; 13]:

$$
\mathrm{M} 1 \mu=P_{\text {гр }} \bar{\Omega} \text { при } P_{\text {гр }} \geq 1 .
$$

ЗгіАно з формулами (5) і (9), грошовий Аефмятор $P_{\text {гр, }}$ змінюючи пропорційно суму M1, не впливає на швиАкість обігу грошей $\mu$. Реальна їх вартість тотожна відношенню суми M1 Ао грошового Аефмятора:

$$
M^{*} \equiv \frac{\mathrm{M} 1}{P_{\text {гр }}}
$$

Відповідно до формул (9) і (10), швидкість обігу грошей за реального сукупного попиту не залежить віА суми готівки та Аепозитів на вимогу M1:

$$
\mu=\frac{\bar{\Omega}}{M^{*}} .
$$

Попит на гроші $M^{D}$ економічних суб'єктів Аця угоА купів ставки процента ЦБ $(i)$ визначається функцією $[12 ; 13]$ :

$$
M^{D}=\mathrm{M} 1=P_{\text {гр }} \sqrt{\frac{0,5 b \bar{\Omega}}{i}},
$$

Ае $b$ - реальна вартість зняття грошей з рахунку в банку.

\section{Модель розвитку економіки}

ЗгіАно з формулою (3), зміна реального ВВП у цінах попереАнього року вимірюється віАношенням реального ВВП $\Omega_{t}$ року $t$ Ао номінального ВВП $\omega_{t-1}$ попереднього року $t-1$ :

$$
\delta_{t}=\frac{\Omega_{t}}{P_{t-1} \Omega_{t-1}}-1
$$

СпаА реацьного ВВП, тобто $\delta_{t}<0, \epsilon$ характерним Аля кризових явищ. Сукупний попит у поточному році, віАповіАно Ао формули (4), залежить віА попиту виробничого сектору на капітал, тобто віА інвестицій у виробництво $R_{\text {вр }}$. Реальна вартість капіталу, наявного в році $t-1$ у сфері виробництва $K_{\text {вр } t-1}$, при 
обліку в націонацьному рахівництві на початок наступного року $t$ у фактичних цінах $K_{\text {вр } t}$ збільшується пропорційно Аефмятору ВВП попереАнього року [17]:

Ае $A$ - амортизація.

$$
K_{\mathrm{Bp} t}=P_{t-1} K_{\mathrm{Bp} t-1}+R_{\mathrm{Bp} t-1}-A_{t-1},
$$

Попит виробництва на інвестиції визначається амортизацією $A$ використовуваного у сфері виробництва капіталу вартістю $K$ і чистими інвестиціями $J_{\text {ч}}, R_{\text {вр }}=A+J_{\text {ч }}$. Елементом націонацьних систем бухгалтерського обліку $€$ Міжнародний стандарт фінансової звітності (IAS) 16 “Основні засоби", Регламент № 1606/20026, IV і VII Аирективи Комісії ЄEC щодо фінансової звітності [18]. У вказаному стандарті зазначено, що амортизоване майно приймається на облік за первинною вартістю і розподіцяється за амортизаційними групами віАповіАно Ао термінів його корисного використання. Суттєвим Ажерелом інвестицій у виробництво $є$ амортизаційні відрахування $A=P \theta K$ із використовуваного у виробництві капіталу при нормі амортизації $\theta$. Чисті інвестиції $\epsilon$ частиною чистого прибутку Ч виробництва з використовуваного капіта у, інша частина $A_{A \Gamma} \in$ Аоходом Аомашніх господарств із капіталу, $\Psi=J_{ч}+A_{A r}$. Інвестиції, більші віА амортизації, забезпечуються чистими інвестиціями. Ажерелом зростання реального ВВП, збільшення

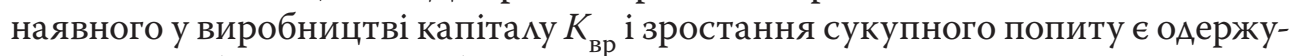
ваний виробництвом прибуток $\pi$ із використовуваного капітацу $K$. Частина

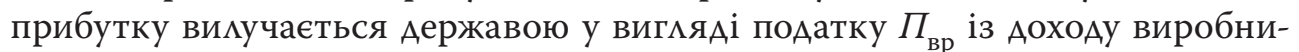
цтва та витрачається на утримання невиробничої сфери й пенсійне забезпечення населення. Реацьний чистий прибуток виробництва за ставки $\chi$ податку $\Pi_{\text {вр }}=\chi Y$ з доходу виробництва $Y=\omega-A$, визначається функцією $\mathcal{u}=\frac{\Psi}{P}=(1-\chi)(\Omega-\theta K)-w B$, де $w=\frac{W}{P}-$ реальна зарплата, $W-$ номінацьна зарпката, $B$ - кількість працюючих у виробництві. ЗвіАси, при виплаченій в країні реальній зарплаті $w B$ завжди існує норма амортизації простого віАтворення капіталу $\bar{\theta}=\frac{\Omega-w B}{(1-\chi) K}$ і визначається закон чистого прибутку:

За норми амортизації простого віАтворення капіталу, $\theta=\bar{\theta}$, та інвестиціях, менших від амортизації, $R_{\text {вр }}<A$, можмиве тільки звужене відтворення капіта у, тобто віАбувається його “проїАання". Межею норми амортизації $\epsilon$ норма вибуття капіталу з експлуатації $\theta_{\text {виб. }}$ що визначається його фізичним зносом і морахьним старінням. У межах $\theta_{\text {виб. }}<<\bar{\theta}$ зАійснюється прискорена амортизація капіталу, яка стимулюється піцьговим оподаткуванням. Норма амортизації, менша за норму вибуття, $\theta<\theta_{\text {виб. }}$ зменшує наявний у сфері виробництва капіта н на величину недоамортизації, $\Delta=\left(\theta_{\text {виб. }}-\theta\right) K P$, тому вартість наявного у виробництві капіталу, котра враховується націонацьною системою бухгалтерського обліку, визначається функцією:

$$
K_{\mathrm{вр} t}=P_{t-1} K_{\mathrm{вp} t-1}+J_{\mathrm{q} t-1}-\bar{\Delta}_{t-1}
$$

де $\bar{\Delta}=\Delta-J_{i}-$ різниця недоамортизації капітаку $\Delta$ і зарубіжних інвестицій у сферу виробництва $J_{i}$. 
У реальній економіці капітал у сфері виробництва використовується не повністю, а залежно віА кон'юнктури сукупного попиту, пропорційно коефіцієнту використання $v, K=v K_{\text {вр }}$ [19]. ПіАприємці регулюють обсяги виробництва в році $t$ за величиною продажів у попередніх роках шляхом зміни чисе ьності працюючих $B_{t}$ віАносно їх кількості в попереАньому році $B_{t-1}$ за кон'юнктурою сукупного попиту $\mathfrak{R}_{t}, B_{t}=\mathfrak{R}_{t} B_{t-1}$. Кон'юнктурне коригування піАприємцями чисемьності працюючих спричиняє пропорційну зміну використання капіталу:

$$
v_{t}=v_{t-1} \Re_{t}=v_{t-1} \frac{B_{t}}{B_{t-1}} .
$$

Ринкова рівновага може спостерігатися за рівноваги на ринках грошей і благ та за наявності безробіття на ринку праці $[11 ; 13]$. Фактичне безробіття Аорівнює різниці повної зайнятості населення в економіці $N_{0}$ і фактичної кількості працюючих $N$ :

$$
f_{\phi}=N_{0}-N
$$

На ринку праці рівновага настає в разі відсутності безробіття, тобто коли $f_{\phi}=0$. ЗвіАси визначається рівень фактичного безробіття:

$$
\varphi=\frac{f_{\phi}}{N_{0}}=\frac{N_{0}-N}{N_{0}} .
$$

За реацьної зарплати $w \geq \frac{12 \partial}{1+n}$, Ае $\partial=\frac{A_{A \Gamma}}{T P}-$ реацьний дохіА Аомашніх господарств із капіталу на одного жителя країни; $T$ - чисельність населення; $n$ - ставка пенсійного податку із заробітної плати, пропозиція праці може бути прийнятою рівною кількості повної зайнятості населення, $N_{0} \approx$ $\approx N^{S}\left[w=\frac{12 \partial}{1+n}\right]=0,46 T[12 ; 13]$.

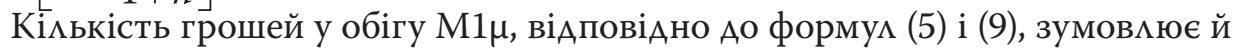
обмежує грошовий сукупний попит на ринку благ, тобто номінальний ВВП, та визначає рівновагу рівністю попиту й пропозиції:

$$
\omega=P_{\mathrm{rp}} \bar{\Omega}=P \Omega=\mathrm{M} 1 \mu .
$$

Величина реального ВВП апроксимується функцією кількості працюючих $B$ у сфері виробництва та капітаку вартістю $K$ :

$$
\Omega=\sigma Q=\sigma B^{\frac{1}{\ln k_{0}}} K^{1-\frac{1}{\ln k_{0}}},
$$

Ае $Q$ - реальний валовий випуск, $\sigma$ - коефіцієнт матеріалоємності виробництва; $k_{0}=\frac{K}{B_{0}}-$ рівноважна капіталомісткість праці, $B_{0}=\xi N_{0}-$ чисельність працюючих у виробництві за повної зайнятості населення в економіці; $\xi=\frac{B}{N}-$ коефіцієнт працюючих у виробництві, $\frac{1}{\ln k_{0}}-$ коефіцієнт технології виробництва $[12 ; 13]$. 
У разі відсутності безробіття, $N=N_{0}$, забезпечується рівновага на ринку праці з рівноважною реацьною зарплатою $w_{0}=\frac{k_{0}}{e \ln k_{0}}$, Ае $e=2,71828$, та реальним сукупним попитом $\bar{\Omega}=\Omega\left(N_{0}\right)=\sigma Q_{0}=\sigma K e^{-1}$, який $\epsilon$ ринковим реа ьним сукупним попитом згіАно з формуками (4) і (5), $\bar{\Omega}=\frac{\omega}{P_{\text {гр }}}$. Отже, коефіцієнт технології виробництва Аорівнює частці оплати праці у вартості рівноважного реального валового випуску $Q_{0}$, або віАношенню рівноважної зарплати й досягнутої продуктивності праці, $\frac{1}{\ln k_{0}}=\frac{w_{0} B_{0}}{Q_{0}}$. А кількість грошей у обігу, віАповіАно Ао формули (6), пропорційна вартості використовуваного капіта у $K$ :

$$
\mathrm{M} 1 \mu=P_{\mathrm{rp}} \sigma K e^{-1} .
$$

ЗгіАно з формулами (18)-(20) визначається виробничий дефкятор віАношенням реацьного сукупного попиту до реальної пропозиції благ:

$$
P_{\text {вр }}=\frac{\bar{\Omega}}{\Omega}=\left(\frac{N_{0}}{N}\right)^{\frac{1}{\ln k_{0}}}=(1-\varphi)^{-\frac{1}{\ln k_{0}}},
$$

та рівність Аефлятора ВВП Аобутку грошового й виробничого Аефляторів, $P=P_{\text {гр }} P_{\text {вр }}$ Аефлятор ВВП, або інфмяція $p=P-1$, як результат регулювання ЦБ кількості грошей та інфляційного регулювання рівноваги на ринку благ, $\epsilon$ функцією грошового Аефмятора й рівня фактичного безробіття:

$$
P=P_{\text {гр }}(1-\varphi)^{-\frac{1}{\ln k_{0}}} .
$$

ЗвіАси віАповіАно до формул (19)-(22) випливає закон розвитку економіки: збільшення капіталу, використовуваного у виробництві, знижує безробіття та інфмяцію, піАвищує виробництво благ, визначає необхіАне зростання грошей.

\section{Фінансове регумювання розвитку економіки}

За рівноваги на ринку грошей, розширеного відтворення використовуваного у виробництві капіталу, $K_{t}>P_{t-1} K_{t-1}$, та наявності безробіття рівняння (9), (17) і (19) описують інфляційне саморегулювання стабільної ринкової рівноваги:

$$
\mathrm{M} 1 \mu=P_{\text {гр }} \bar{\Omega} ; P \Omega=P_{\text {гр }} \bar{\Omega} ; f_{\phi}=N_{0}-N \text { при } K_{t}>P_{t-1} K_{t-1}, P>1, N<N_{0} .
$$

Умовами стабільної ринкової рівноваги $\epsilon$ наявність інфмяції, тобто дефмятор ВВП, бі цьший за одиницю, $P>1$, та наявність безробіття, $f_{\phi}>0$. Якщо кількість працюючих у країні більша за розрахункову кількість зайнятих, $N>N_{0}$, віАповіАно до формул (17) і (18) безробіття і його рівень будуть віА'ємними, $f_{\phi}<0$. Така ситуація призводить, згідно з рівнянням (20), Ао перевищення реацьною пропозицією благ реацьного сукупного попиту $\bar{\Omega}$, $\Omega>\bar{\Omega}$ при $N>N_{0}$, тому може бути порушена рівновага в реальному секторі економіки через перевиробництво благ. Аля забезпечення рівноваги на 
ринку благ при $N>N_{0}$ ЦБ повинен забезпечити таку кількість грошей у обігу $\mathrm{M} 1 \mu$, яка переважатиме реальну пропозицію благ $\Omega$, зі знеціненням грошей пропорційно дефлятору ВВП, $\mathrm{M} 1 \mu=P \Omega$ при $P>1$. Врівноважене нестабільне саморегулювання ринкової рівноваги в реальному секторі описується системою рівнянь:

$$
\mathrm{M} 1 \mu=P \Omega ; P \Omega=P_{\text {гр }} \bar{\Omega} ; f_{\phi}=N_{0}-N \text { при } K_{t}>P_{t-1} K_{t-1}, N>N_{0}, P>1 .
$$

Аналіз фінансового регулювання рівноваги економіки України у 20072013 pp. зАійснено на підставі Ааних табА. 1. При цьому використано такі показники: коефіцієнт працюючих у виробництві $\xi=0,75$, інвестиційний попит виробництва $R_{\text {вр }}=0,2 \omega$, амортизаційні відрахування $A=0,02 K$, чисті інвестиції $J_{\mathrm{\varphi}}=0,2(\omega-0,1 K)$.

Та б $и$ и я 1. Показники анахізу стану економіки України у 2007-2013 pp.

\begin{tabular}{|c|c|c|c|c|c|c|c|c|}
\hline Показники & 2006 & 2007 & 2008 & 2009 & 2010 & 2011 & 2012 & 2013 \\
\hline \multicolumn{9}{|c|}{ Статистичні дані } \\
\hline Чисельність населення T, млн осіб & 46,70 & 46,40 & 46,20 & 46,02 & 45,86 & 45,71 & 45,56 & 45,44 \\
\hline Зайняті у виробництві $B$, млн осіб & 13,8 & 14,25 & 14,32 & 12,436 & 13,265 & 13,868 & 13,717 & 13,666 \\
\hline 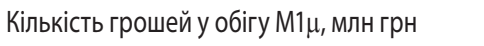 & 544000 & 721000 & 948000 & 913000 & 1080000 & 1300000 & 1405000 & 1465000 \\
\hline Грошова база H, млн грн & 97214 & 141901 & 186671 & 194965 & 225692 & 239885 & 255283 & 307139 \\
\hline Депозити на вимогу $D_{1}$, млн грн & 48292 & 70548 & 70389 & 76719 & 106904 & 118382 & 119980 & 146044 \\
\hline Строкові депозити $D_{2}$, млн грн & 138138 & 209608 & 287402 & 253535 & 307841 & 370754 & 447938 & 522416 \\
\hline Довгострокові депозити $D_{3}$, млн грн & 1650 & 4884 & 3200 & 2526 & 1031 & 3714 & 2072 & 2758 \\
\hline Кредити банків $\Xi$, млн грн & 151705 & 247150 & 406283 & 419627 & 454919 & 518093 & 547735 & 641431 \\
\hline \multicolumn{9}{|c|}{ Розрахункові дані } \\
\hline Виробничий капітал Квр, млн грн & 3028860 & 3541960 & 4406452 & 5751741 & 6598017 & 7606399 & 8779658 & 9545614 \\
\hline Коефіцієнт використання капіталу v & 0,915 & 0,945 & 0,95 & 0,825 & 0,88 & 0,92 & 0,91 & 0,906 \\
\hline Працюючий капітал K, млн грн & 2771401 & 3347150 & 4186129 & 4745187 & 5806255 & 6997910 & 7989489 & 8648326 \\
\hline Зайняті в економіці $N$, млн осіб & 18,4 & 19,0 & 19,09 & 16,581 & 17,687 & 18,49 & 18,289 & 18,221 \\
\hline Рівноважна праця $N_{0}$, млн осіб & 21,482 & 21,344 & 21,252 & 21,169 & 21,096 & 21,047 & 20,958 & 20,889 \\
\hline Рівень фактичного безробіття $\varphi, \%$ & 14,35 & 10,98 & 10,17 & 18,37 & 16,16 & 12,15 & 12,73 & 12,77 \\
\hline $\begin{array}{l}\text { Рівноважна капіталомісткість праці } k_{0} \\
\text { грн/особу }\end{array}$ & 172014 & 209092 & 262634 & 296712 & 366887 & 443320 & 509463 & 552018 \\
\hline Коефіцієнт технології виробництва 1/Ink & 0,083 & 0,0816 & 0,0801 & 0,0793 & 0,078 & 0,0769 & 0,0761 & 0,0756 \\
\hline Реальний ВВП $\Omega$, млн грн & 473630 & 585672 & 737808 & 804002 & 948422 & 1139514 & 1302782 & 1405042 \\
\hline Зміна реального ВВП $\delta$ & 0,073 & 0,076 & 0,0237 & $-0,152$ & 0,038 & 0,055 & 0,002 & 0 \\
\hline Виробничий дефлятор $P_{\text {вр }}$ & 1,0129 & 1,0095 & 1,0086 & 1,0195 & 1,0138 & 1,01 & 1,0104 & 1,0104 \\
\hline Грошовий дефлятор $P_{\text {гр }}$ & 1,136 & 1,258 & 1,275 & 1,114 & 1,126 & 1,13 & 1,0668 & 1,032 \\
\hline Дефлятор ВВП P & 1,15 & 1,227 & 1,286 & 1,136 & 1,142 & 1,141 & 1,078 & 1,043 \\
\hline Номінальний ВВП $\omega$, млн грн & 544675 & 720376 & 948821 & 913346 & 1083098 & 1300185 & 1404399 & 1465458 \\
\hline Чисті інвестиції $J_{4}$, млн грн & 69833 & 77203 & 105975 & 87765 & 100495 & 120534 & 121090 & 120125 \\
\hline Норматив резервів, встановлений ЦБ, $\alpha$ & 0,46 & 0,436 & 0,453 & 0,494 & 0,399 & 0,399 & 0,434 & 0,468 \\
\hline $\begin{array}{l}\text { Відношення готівки до депозитів } \\
\text { на вимогу } \beta\end{array}$ & 1,55 & 1,58 & 2,12 & 2,05 & 1,7 & 1,63 & 1,7 & 1,60 \\
\hline Мультиплікатор m & 1,268 & 1,286 & 1,206 & 1,199 & 1,285 & 1,296 & 1,266 & 1,256 \\
\hline M1, млн грн & 123267 & 181633 & 225125 & 233763 & 290014 & 310891 & 323188 & 385830 \\
\hline
\end{tabular}


Закінчення табл. 1

\begin{tabular}{|l|r|r|r|r|r|r|r|r|}
\hline \multicolumn{1}{|c|}{ Показники } & $\mathbf{2 0 0 6}$ & $\mathbf{2 0 0 7}$ & $\mathbf{2 0 0 8}$ & $\mathbf{2 0 0 9}$ & $\mathbf{2 0 1 0}$ & $\mathbf{2 0 1 1}$ & $\mathbf{2 0 1 2}$ & $\mathbf{2 0 1 3}$ \\
\hline Швидкість обігу грошей $\mu$ & 4,414 & 3,968 & 4,211 & 3,907 & 3,733 & 4,181 & 4,346 & 3,798 \\
М0, млн грн & 74984 & 111119 & 154759 & 157029 & 182990 & 192685 & 203245 & 237777 \\
М2, млн грн & 259413 & 391273 & 512527 & 484772 & 596841 & 681801 & 771126 & 906236 \\
М3, млн грн & 261063 & 396156 & 515727 & 487298 & 597872 & 685515 & 773199 & 908994 \\
Банківські резерви $P_{\text {м }}+P_{\mathrm{H}^{\prime}}$ млн грн & 22230 & 30782 & 31912 & 37936 & 42702 & 47200 & 52038 & 69362 \\
Кредитна база $\Xi$, млн грн & 164049 & 254255 & 329056 & 292333 & 372180 & 445630 & 517916 & 601855 \\
Фінансовий резерв \&, млн грн & 12344 & 7105 & -77227 & -127294 & -82739 & -72463 & -29819 & -39576 \\
\hline
\end{tabular}

Розраховано та скмадено за: Наличие и состояние основных средств по видам экономической Аеяте ьности (КВЭА-2010) в 2013 году / Государственная служба статистики Украины. URL: https://ukrstat.org/operativ/operativ2013/ibd/nsoz/nsoz13_r.htm; Аані Аержавної служби статистики України (http://www.ukrstat.gov.ua/); Бюлетень Націонамьного банку України. 2006. № 1-12 (140-151); Бюлетень Націонахьного банку України. 2010. № 1-12 (202-213); Бюлетень Націонацьного банку України. 2014. № 1-12 (250-261).

Як бачимо з табл. 1, банківська рівновага, відповідно (8), яка забезпечує позитивний баланс $\varepsilon>0$, зберігалась у 2006 і 2007 рр. У 2008 р. в умовах світової фінансової кризи за потурання НБУ вона була порушена з Аефіци-

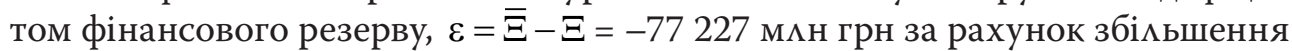
в 1,73 раза кредитів, виданих за рік. Унаслідок цього банківська система увійшла в глибоку креАитну кризу, за котрої банківські резерви не покрили Аефіцит, $P_{\text {м }}+P_{\text {н }}+\varepsilon=-45312$ млн грн. Банки у 2008 р. припиними креАитування оАин оАного, єАИним креАитором залишився НБУ, але реальний сектор за інфмяції 28,6 \% забезпечив зростання реального ВВП на 2,37 \% (що є спадом відносно зростання на 7,6 \% у 2007 р.). У 2009 р. піА час креАитної кризи, коли $\varepsilon=-127294$ млн грн, кризові явища посили ись і віАбувся спаА реа ьного ВВП $(\delta=-15,2 \%)$. Заходами НБУ по зміні кі ьькості грошей в обі-

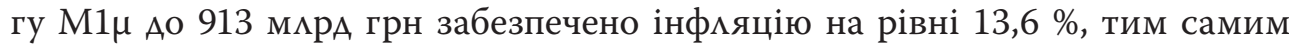
не Аопущено гіперінфмяції. Протягом 2010-2013 рр. зменшився Аефіцит фінансового резерву за рахунок збільшення грошової маси МЗ при інфмяції $p=P-1$ віА 14,2 Ао 4,3 \%. Зростання реального ВВП припиникось у 2012 р., водночас піАвищився рівень безробіття. У 2012-2013 рр. креАитна криза триваца, оскільки існував дефіцит фінансового резерву $\varepsilon<0$.

\section{Грошова дефмяція}

Виробничий Аефлятор за наявності безробіття завжАи, згіАно з формумою (22), більший віА оАиниці. Тому в разі наявності безробіття віАповіАно Ао рівняння (17) та грошового Аефмятора, меншого за оАиницю, тобто при порушеній унаслідок грошової Аефляції рівновазі на ринку грошей (Аив. рівняння (9)), можиива стабільна рівновага економіки (Аив. формулу (24)), $P=$ $=P_{\text {гр }} P_{\text {вр }}>1$, із незначною інфляцією. Стабі ььна рівновага економіки з нульовою інфляцією можлива за граничного грошового Аефлятора, що Аорівнює зворотній величині виробничого Аефмятора [13]:

$$
\bar{P}_{\text {гр }}=(1-\varphi)^{\frac{1}{\ln k_{0}}} \text {. }
$$


При розширеному відтворенні завантаженого у сфері виробництва капітаку, за наявності безробіття й порушеної рівноваги на ринку грошей через грошову дефляцію з величиною грошового Аефлятора, меншою віА одиниці та більшою за граничне значення, $1>P_{\text {гр }}>(1-\varphi)^{\frac{1}{\ln k_{0}}}$, забезпечується тривале саморегулювання рівноваги згіАно з рівнянням (24) із низьким зростанням реального ВВП, котре $\epsilon$ Аепресією реального сектору економіки. При грошовому дефмяторі, меншому віА граничного, $P_{\text {гр }}<(1-\varphi)^{\frac{1}{\ln k_{0}}}$, у реальному секторі віАбувається дефмяція, на межі якої балансують економіки розвинутих країн після початку кризи у 2008 р.

У разі нестабільної рівноваги (Аив. рівняння (25)) виробничий дефлятор, віАповіАно Ао формули (22), завжАи менший за одиницю, а грошовий, згіАно 3 рівнянням (23), - постійно більший віА одиниці. Нестабільна рівновага (Аив. формуку (25)) із нульовою інфмяцією, $P=1$, можлива за граничного грошового Аефлятора, що Аорівнює зворотній величині виробничого Аефлятора згіАно з рівнянням (26). У разі надмірної чисельності працюючих, розширеного відтворення використовуваного у сфері виробництва капіталу та грошового Аефмятора, який перевищує граничний, $P_{\text {гр }}>(1-\varphi)^{\frac{1}{\ln k_{0}}}$, забезпечується тривале зростання реального ВВП.

Аля прискорення виходу із кризи 2008 р. ЦБ провіАних розвинутих країн, а саме США (ФРС), єврозони (ЄЦБ), Японії (Банк Японії), Великобританії (Банк Англії), з метою забезпечення річної інфцяції на рівні не більш ніж $2 \%$ викуповували активи з балансів банків та знижували процентні ставки Ао нуля. Вони віАповіли на кризу різким накачуванням грошей у економіки своїх країн. Грошові бази ЦБ США, Великобританії, Європейського Союзу, Японії зросли протягом 2010-2013 рр. у 3-5 разів [20]. ОАнак політика нуАьових процентних ставок і різкого збільшення грошових баз не змогла піАвищити інфмяцію до $2 \%$. У єврозоні та Японії інфмяція перебуває на рівні $0,25 \%$ і йде в бік дефмяції [21].

Графіки залежності у відсотках віА рівня безробіття граничних значень грошової інфцяції $\bar{p}_{\text {гр }}=\bar{P}_{\text {гр }}-1=(1-\varphi)^{\frac{1}{\ln k_{0}}}-1$ зображені на рисунку за коефіцієнтів технології виробництва $\left(\frac{1}{\ln k_{0}}\right)$ 0,1; 0,075; 0,0666, визначених віАповідно до рівноважної реальної заробітної плати $\left(w_{0}=\frac{k_{0}}{e \ln k_{0}}\right) 810,19$ 877, 80172 умовних одиниць (у. о.) [13]. Інфмяція 0,25 \% у $\in C$ і Японії за безробіття понад 6 \% визначає наявність грошової дефмяції більш ніж 0,2 \%. Аля виходу з депресії та стимулювання зростання реального ВВП необхіАна кімькість грошей у обігу з грошовим Аефцятором, що перевищує оАиницю.

Зміну дефцятора ВВП можливо виразити в залежності віА номінальної заробітної плати $W$ в країні. Номінальна зарплата $W_{t}$ поточного року $t$ може бути визначена тільки системою національного рахівництва в результаті 


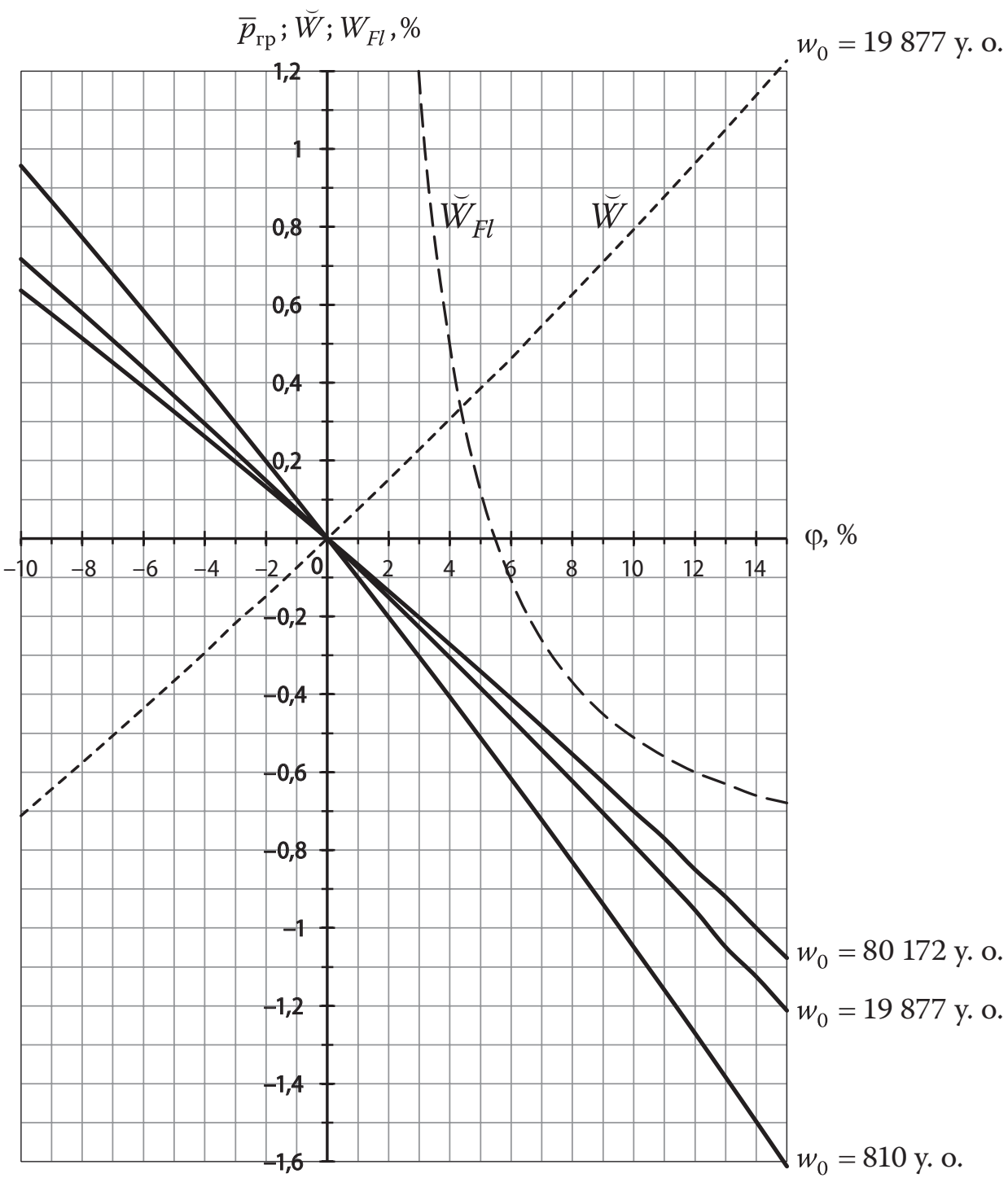

Р и с унок. Залежність граничних значень грошової інфмяції $\bar{p}_{\text {гр }}$ i темпу зростання заробітної пьати $W$ віА рівня безробіття $\varphi$

Побудовано авторами.

бухгалтерського обліку за піАсумками року через Аефмятор ВВП $P_{t}$ і реальну заробітну плату $w_{t}$, тобто $W_{t}=P_{t} w_{t}$. При коефіцієнті $z_{t}$ зміни за рішенням Уряду країни зарп ати на початок поточного року $t$, порівняно з попереАнім $w_{\mathrm{c} t}=z_{t} w_{\mathrm{c} t-1}$, визначається реальна зарплата $w_{t}=z_{t} W_{t-1}$ [22]. ЗвіАси вип ииває наявна в економіці залежність темпу зміни зарплати $\breve{W}_{t}=\frac{W_{t}-W_{t-1}}{W_{t-1}}$ віА рівня безробіття віАповіАно Ао формули (23): $\breve{W}=z P_{\text {гр }}(1-\varphi)^{-\frac{1}{\ln k_{0}}}-1$. 
Темп зміни зарплати $є$ нульовим за граничних значень грошового дефмятора й коефіцієнта зміни $z$, що Аорівнює одиниці, тобто за умови безінфцяцій-

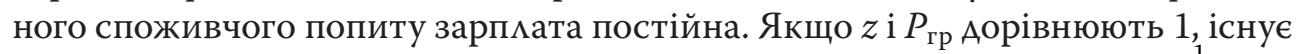
залежність темпу зміни зарплати $\breve{W}$ віА рівня безробіття $\breve{W}=(1-\varphi)^{-\frac{1}{\ln k_{0}}}-1$, графік якої при рівноважній зарплаті $w_{0}=19877$ у. о. наведено на рисунку. Із графіка зрозуміло, що темп зростання зарплати завжди збільшується 3 піАвищенням рівня безробіття. ОАнак у економічній теорії Аля вимірювання макроекономічних показників досі використовується помилкова залежність темпу зміни зарплати віА рівня безробіття, описувана в процентах емпіричною кривою Фі $і$ іпса $\breve{W}_{F l}=-0,9+9,638 \varphi^{-1,394}[23 ; 24]$. На Аумку Р. Барро та В. Гріл і, чимало макроекономічних теорій, що виникци з 1930-х років, можна інтерпретувати як різні версії кривої Філіпса й пов'язаних із ними обгрунтувань нейтральності грошей [25]. Тобто крива Філіпса широко застосовується в макроекономіці. Вона визначає не кише зниження інфцяції з посиленням безробіття, а й можмивість негативної інфмяції (дефмяції) за більшого віА одиниці коефіцієнта зміни зарплати, $z_{t} \geq 1$, та високого безробіття. Тому в макроекономіці Аля пошуку “оптима ьного поєАнання темпу інфмяції й рівня безробіття” Аосі застосовуються модифіковані криві Філіпса [26, с. 90, 91].

Графік кривої Філіпса на рисунку $W_{F l}$ порівняно з графіком $\breve{W}$ засвідчує поми ковість уявлень про зменшення зарп ати зі зростанням рівня безробіття. Як наслідок, сформувалося уявлення про зниження інфцяції $з$ піАвищенням рівня безробіття, оскільки $\breve{W}=p$ при $z=1$ [22, с. 141], $p_{F l}=W_{F l}=$ $=-0,9+9,638 \varphi^{-1,394}$ при $z=1$. Попри це, ЦБ розвинутих країн Аотепер використовують прогнозні моделі макроекономіки, котрі послуговуються кривою Фі-

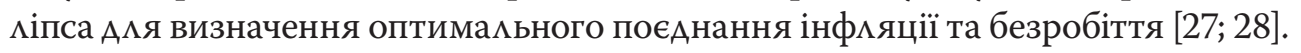

\section{Умови економічного зростання}

Обов'язковими умовами зростання ВВП є розширене відтворення капіталу, наявного у сфері виробництва, $K_{\text {вр } t}>P_{t-1} K_{\text {вр } t-1}$, і використовуваного у виробництві, $K_{t}>P_{t-1} K_{t-1}$; збільшення використання виробничого капіта у, $v_{t}>v_{t-1}$; ринкова рівновага, $P>1$. Нарощення використовуваного виробничого капітацу можииве в разі поліпшення кон'юнктури сукупного попиту, на котру впливають такі кон'юнктури, як ринкова та ризиків і стимулів [13]. Факторами ризиків є стихійні миха, війни, революції, катастрофи, зміни активності сонця, світові кризи, виплати державних боргів, зростання комуна ьних тарифів, погіршення соціального забезпечення, а стимулів - піАвищення оплати праці, створення нових робочих місць, поліпшення соціального забезпечення, інфраструктурне будівництво. Причинами зниження кон'юнктури попиту є: обмеження ЦБ і фінансовим сектором кількості грошей у обігу, звужене відтворення завантаженого у сфері виробництва капіталу, зростання матеріацомісткості виробництва, а також Аія факторів ризиків і стимулів.

Кон’юнктура попиту Аорівнює Аобутку ринкової кон'юнктури $\mathfrak{R}_{\mathrm{p}}$ та кон'юнктури ризиків і стимулів $\mathfrak{R}_{r s}, \mathfrak{R}=\mathfrak{R}_{\mathrm{p}} \mathfrak{R}_{r s}$. У разі наявності інфцяції, $P>1$, 
ринкова кон'юнктура в році $t$ визначається піАприємцями за темпом зміни обсягу продажів $1+\delta_{t-1}$ у попередньому році за вирахуванням зміни обсягу продажів $\delta_{t-2}$ в році, що передував йому, $t-2$. А за умови дефляції, $P<1$, ринкова кон'юнктура в році $t$ встановцюється за рівнем продажів, тобто цін, у попередньому році $[12 ; 13]$ :

$$
\mathfrak{R}_{\mathrm{p} t}=\left\{\begin{array}{l}
1+\delta_{t-1}-\delta_{t-2} \text { при } P_{t-1}>1 ; \\
P_{t-1} \text { при } P_{t-1}<1
\end{array}\right.
$$

Кон'юнктура ризиків і стимулів у році $t$ визначається добутком коефіцієнтів Аіючих факторів $\aleph_{i t}$ :

$$
\mathfrak{R}_{r s t}=\aleph_{1 t} \aleph_{2 t} \ldots \aleph_{v t}
$$

У табл. 2 наведено можливі макроекономічні показники на 2018-2020 pp. згіАно зі статистичними даними за 2016 і 2017 рр. при $\sigma=0,445$ (за апроксимації показників табл. 1). У 2019 і 2020 рр. існує кон'юнктура стимулів у зв'язку $з$ піАвищенням заробітної плати, віАповіАно, 1,011 та 1,012. При моделюванні використано показники, що скмалися в попереАні роки [29]. З’ясовано, що за прийнятих вхіАних віАомостей за роками можливий спаА зростання

\begin{tabular}{|c|c|c|c|c|c|}
\hline Показники & 2016 & 2017 & 2018 & 2019 & 2020 \\
\hline \multicolumn{6}{|c|}{ Вхідні відомості } \\
\hline Чисельність населення T, млн осіб & 42,5 & 42,3 & 42,1 & 41,9 & 41,7 \\
\hline Кількість грошей у обігу М1 $\mu$, млн грн & 2380000 & 2850000 & 3250000 & 3650000 & 4100000 \\
\hline \multicolumn{6}{|c|}{ Результати моделювання } \\
\hline 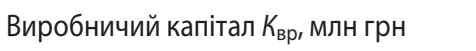 & 16182499 & 19154671 & 22344076 & 25105658 & 28564416 \\
\hline Ринкова кон'юнктура $\mathfrak{R}_{\mathrm{p}}$ & 0,97 & 1,02 & 1,011 & 0,99 & 0,97 \\
\hline Зайняті у виробництві $B$, млн осіб & 11,01 & 11,23 & 11,354 & 11,24 & 10,9 \\
\hline Коефіцієнт використання капіталу v & 0,79 & 0,81 & 0,82 & 0,812 & 0,79 \\
\hline Працюючий капітал K, млн грн & 12784174 & 15515284 & 18322142 & 20385794 & 22565889 \\
\hline Зайняті в економіці $N$, млн осіб & 14,68 & 14,97 & 15,138 & 14,98 & 14,53 \\
\hline Рівноважна праця $N_{0}$, млн осіб & 19,55 & 19,458 & 19,37 & 19,274 & 19,182 \\
\hline Рівень фактичного безробіття $\varphi, \%$ & 24,9 & 23,05 & 21,8 & 22,28 & 24,25 \\
\hline Реальний ВВП $\Omega$, млн грн & 2034430 & 2445587 & 3073100 & 3594603 & 3960642 \\
\hline Реальний попит $\bar{\Omega}$, млн грн & 2069337 & 2511413 & 3130602 & 3608565 & 4033807 \\
\hline Зміна реального ВВП $\delta, \%$ & 2,38 & 2,6 & 3,02 & 2,7 & 2,5 \\
\hline Виробничий дефлятор $P_{\text {вр }}$ & 1,021 & 1,027 & 1,019 & 1,015 & 1,019 \\
\hline Грошовий дефлятор $P_{\text {гр }}$ & 1,150 & 1,188 & 1,118 & 1,085 & 1,066 \\
\hline Дефлятор ВВП P & 1,171 & 1,220 & 1,139 & 1,110 & 1,086 \\
\hline Номінальний ВВП $\omega$, млн грн & 2383182 & 2983616 & 3500260 & 3911042 & 4300974 \\
\hline Чисті інвестиції $J_{4}$ млн грн & 220338 & 259698 & 317733 & 341390 & 367385 \\
\hline
\end{tabular}

\section{Та бл и ц я 2. Можмиві макроекономічні показники України на 2018-2020 pp.}

Розраховано та скмадено за: World Economic Outlook Database. 2017. URL: https://www.imf.org/ external/pubs/ft/weo/2017/02/weodata/index.aspx; World Economic Outlook Database. 2018. URL: https://www.imf.org/external/pubs/ft/weo/2018/02/weodata/index.aspx. 
реального ВВП з 2019 р. у зв'язку з недостатнім обсягом інвестицій у виробничий капіта , що віАповіАає прогнозу МВФ [30]. А я забезпечення зростання реального ВВП у 2019-2020 рр. на рівні 3 \% необхідно було б збільшити їх уАвічі, починаючи з 2018 р. [31].

На піАставі викцаденого Аоходимо висновків, що Аля реалізації Цікей стамого розвитку потрібні: по-перше, зростання реального ВВП, яке можливе тільки в результаті розширеного віАтворення виробничого капіталу та регуАювання центрацьним банком кількості грошей в обігу; по-Аруге, досягнення ринкової рівноваги завдяки саморегулюванню інфцяції, тобто за умов, що Аефмятор ВВП перевищує одиницю; по-третє, постійного балансування центральним банком попиту і пропозиції на ринку грошей.

Фінансове управ іння макроекономічними процесами вимагає одночасного використання бюджетно-податкових, амортизаційних, інвестиційних і ринкових інструментів тощо.

\section{Список використаних Ажерек}

1. Global Goals for Sustainable Development / UN. URL: https://www.un.org/ sustainabledevelopment/.

2. Про стратегію сталого розвитку “Україна - 2020" : указ Президента України віА 12.01.2015 № 5/2015. URL: http://zakon0.rada.gov.ua/laws/show/5/2015.

3. Смит А. Исследование о природе и причинах богатства народов. М. : Эксмо, 2007. $960 \mathrm{c}$.

4. Рикардо A. Сочинения : в 5 т. Т. 1: Начала политической экономии и налогового обложения. М. : ГосполитизАат, 1955.339 с.

5. Кейнс Аж. М. Общая теория занятости, процента и Аенег. М. : Гелиос АРВ, 2002. $352 \mathrm{c}$.

6. Фридмен М. Количественная теория денег. М. : Эльф, 1996. 131 с.

7. Canto V. A., Joines D. H., Laffer A. B. Foundations of Supply-Side Economics - Theory and Evidence. N. Y. : Academic Press, 1982.

8. Єбименко T. I. Фіскальна та монетарна безпека національної економіки / АННУ “АкаА. фін. упр.”. Київ, 2016. 447 с.

9. Аюбіч $О$. О. Теоретичні основи прийняття фінансових рішень на макрорівні. Київ, 2004. 348 с.

10. Швець С. М. Короткострокове прогнозування валової Аоданої вартості : монографія / НАН України, АУ “Ін-т економіки та прогнозування". Київ, 2013. 136 с.

11. Горбачук В. М., Аюбіч О. О. Соціально-економічний розвиток ХХ сторіччя: цікі, моделі, дані, стратегії, міри ефективності. Моделювання та інборматизація соціально-економічного розвитку України. 2010. Вип. 11. С. 3-27.

12. Аунаев Б. Б. Благосостояние - труА, капитал и деньги: основы теории воспроизводства. 2-е изА., АоП. Киев : Интерарук, 2013. 231 с.

13. Аунаев Б. Б. Безынфмяционный потребительский спрос. Кибернетика и системный анализ. 2016. № 4. С. 103-117.

14. Панасюк Б., Сергиенко И., Гуляницкий А. Прогнозирование развития экономики Украины. Экономика Украины. 1996. № 1. С. 20-31.

15. Сорос Аж. Алхимия финансов. М. : ИНФРА-М, 1996. 416 с.

16. Фінансова глобалізація і євроінтеграція : монографія / за реА. О. Г. Білоруса, Т. I. Єфименко ; АННУ “Академія фінансового управління". Київ, 2015. 491 с.

17. Ван Хорн Аж. К. Основы управления финансами : пер. с англ. М. : Финансы и статистика, 2000. 800 c. 
18. Regulation (EC) No 1606/2002 of the European Parliament and of the Council of 19 July 2002 on the application of international accounting standards. URL: https://eur-lex. europa.eu/legal-content/EN/TXT/PDF/?uri=CELEX:32002R1606\&from=IT.

19. Сакс А., Ааррен Ф. Макроэкономика. Гцобацьный подход : пер. с англ. М. : Аело, 1999.848 с.

20. ГАобальный мониторинг теневого банкинга - 2013. URL: http://www.groupglobal.org/ru/lecture/view.

21. World Economic Outlook: Too Slow for Too Long / IMF. Washington, DC, 2016. P. $168-177$.

22. Аунаев Б. Б. Функция темпа роста ставки зарплаты от уровня безработицы. Кибернетика и системньй анализ. 2011. № 5. С. 140-149.

23. Phillips $A$. W. The relationship between unemployment and the rate of change of money wage rates in the United Kingdom, 1861-1957. Economica. 1958. Nov. P. 283-299.

24. Горидько Н. П. Моделирование краткосрочной кривой Фимлипса Аля США. Бізнес Інборм. 2012. № 4. С. 49-52. URL: http://nbuv.gov.ua/j-pdf/binf_2012_4_16.pdf.

25. Barro R., Grilli V. Makroökonomie: Europäische Perspektive. München, 1996. 637 S.

26. Моисеев С. Р. Инфмяция: современный взгляА на вечную проблему. М. : ООО "Маркет АС Корпорейшн", 2004. 228 с.

27. Gosselin M.-A., Lalonde R. MUSE: The Bank of Canada's New Projection Model of the U.S. Economy. Bank of Canada Technical Report. 2005. No. 96.

28. Хеммонд Аж. Практика инфцяционного таргетирования - 2012 / Банк Англии. URL: http://www.cbr.ru/dkp/ccbshb29r.pdf.

29. Бюлетень Націонахьного банку України. 2015. № 9-12 (270-273).

30. GDP Annual Growth Rate - Forecast - 2018-2020 / Trading Economics. URL: https://tradingeconomics.com/forecast/gdp-annual-growth-rate.

31. Аунаєв Б. Б., Аюбіч О. О. Модемювання макроекономічних процесів. Математичне моделювання в економіці. 2018. № 1. С. 109-125.

\section{References}

1. UN. (n. d.). Global Goals for Sustainable Development. Retrieved from https://www. un.org/sustainabledevelopment/.

2. President of Ukraine. (2015). On the Strategy of Sustainable Development "Ukraine 2020" (Decree No. 5/2015, January 12). Retrieved from http://zakon0.rada.gov.ua/laws/show/ $5 / 2015$.

3. Smith, A. (2007). An Inquiry into the Nature and Causes of the Wealth of Nations. Moscow: Eksmo [in Russian].

4. Ricardo, D. (1955). The Works and Correspondence. Vol. 1. Principles of Political Economy and Taxation. Moscow: Gospolitizdat [in Russian].

5. Keynes, J. M. (2002). The general theory of employment, interest and money. Moscow: Gelios ARV [in Russian].

6. Friedman, M. (1996). Quantity Theory of Money. Moscow: E'l'f [in Russian].

7. Canto, V. A., Joines, D. H. \& Laffert, A. B. (1982). Foundations of Supply-Side Economics - Theory and Evidence. New York: Academic Press.

8. Yefy'menko, T. I. (2016). Fiscal and monetary security of the national economy. Ky'yiv: DNNU "Akademiya finansovoho upravlinnya" [in Ukrainian].

9. Lyubich, O. O. (2004). The theoretical basis for making financial decisions at the macro level. Ky'yiv: NDFI [in Ukrainian].

10. Shvec', S. M. (2013). Short-term gross value added forecasting. Ky'yiv: DU “Insty'tut ekonomiky' ta prohnozuvannya NAN Ukrayiny'" [in Ukrainian].

11. Horbachuk, V. M., Lyubich, O. O. (2010). Socio-economic development of the 20th century: goals, models, data, strategies, measures of effectiveness. Modeling and informatization of social and economic development of Ukraine, 11, 3-27 [in Ukrainian]. 
12. Dunaev, B. B. (2013). Welfare-Labor, Capital and Money: The Basics of Reproduction Theory. (2nd ed.). Kiev: Interdruk [in Russian].

13. Dunaev, B. B. (2016). Non-inflationary consumer demand. Cybernetics and systems analysis, 4, 103-117 [in Russian].

14. Panasyuk, B., Sergienko, I. \& Gulyanickij, L. (1996). Forecasting the development of the Ukrainian economy. Economy of Ukraine, 1, 20-31 [in Russian].

15. Soros, G. (1996). The Alchemy of Finance. Moscow: INFRA-M [in Russian].

16. Bilorus, O. H., Iefymenko, T. I. (Eds.). (2015). Financial globalization and European integration. Ky'yiv: DNNU "Akademiya finansovoho upravlinnya" [in Ukrainian].

17. Van Horne, J. (2000). Fundamentals of financial management. Moscow: Finance and Statistics.

18. European Parliament and the Council (2002, 19 July). Regulation (EC) on the application of international accounting standards. URL: https:/eur-lex.europa.eu/legal-content/ EN/TXT/PDF/?uri=CELEX:32002R1606\&from=IT.

19. Sachs, J. D., Larrain, F. B. (1999). Macroeconomics in the Global Economy. Moscow: DELO [in Russian].

20. Global monitoring of shadow banking - 2013. (n. d.). www.group-global.org. Retrieved from www.group-global.org/ru/lecture/view [in Russian].

21. International Monetary Fund. (2016, April). World Economic Outlook: Too Slow for Too Long. Washington, DC: Author.

22. Dunaev, B. B. (2011). Function of the dependence of salary growth rate on unemployment rate. Cybernetics and systems analysis, 5, 140-149 [in Russian].

23. Phillips, A. W. (1958). The relationship between unemployment and the rate of change of money wage rates in the United Kingdom, 1861-1957. Economica, 25, 283-299.

24. Gorid'ko, N. P. (2012). Modeling the short-term Phillips curve for the United States. Business Inform, 4, 49-52. Retrieved from http://nbuv.gov.ua/j-pdf/binf_2012_4_16.pdf [in Russian].

25. Barro, R., Grilli, V. (1996). Makroökonomie: Europäische Perspektive. München.

26. Moiseev, S. R. (2004). Inflation: a modern view of the eternal problem. Moscow: Market DS Korporejshn [in Russian].

27. Gosselin, M.-A., Lalonde, R. (2005). MUSE: The Bank of Canada's New Projection Model of the U.S. Economy. Bank of Canada Technical Report, 96.

28. Hammond, G. (2012). State of the art inflation targeting. Bank of England. Retrieved from http://www.cbr.ru/dkp/ccbshb29r.pdf [in Russian].

29. Bulletin of National Bank of Ukraine. (2015). No. 9-12 [in Ukrainian].

30. Trading Economics. (n. d.). GDP Annual Growth Rate - Forecast - 2018-2020. Retrieved from https://tradingeconomics.com/forecast/gdp-annual-growth-rate.

31. Dunaiev, B. B., Liubich, O. O. (2018). Modeling of macroeconomic processes. Mathematical modeling in economy, 1, 109-125 [in Ukrainian]. 